\title{
WOMEN ARTISTS OF THE LATE 19TH CENTURY: CONTINUITY AND CHANGE AT THE SUNSET OF IMPERIAL CHINA
}

\author{
Zhou Xiaoqin ${ }^{1}$ \\ Haji Baharudin bin Haji Mohd Arus² \\ ${ }^{1}$ Akademi Seni dan Teknologi Kreatif (ASTiF), Universiti Malaysia Sabah, \\ Jalan UMS, 88400 Kota Kinabalu, Sabah. \\ ${ }^{2}$ Faculty of Social Sciences and Humanities, Universiti Malaysia Sabah, \\ Jalan UMS, 88400 Kota Kinabalu, Sabah. \\ zhaoming@gmail.com ${ }^{\prime}$; arusbaha@yahoo.com ${ }^{2}$ \\ Received: 18 September 2020 / Accepted: 22 January 2021
}

\begin{abstract}
Increasing attention to the history of Chinese women artists gives further impetus to re-evaluation of their artistic contribution. Here I focus on developments in women's art in the later part of the 19th century, entering into an interrogation of the assumption that the century had witnessed its decline in tandem with the decline of the Imperial China itself. A focus of the article is the 2017 Zhejiang exhibition, which has served to further intensify the imperative for research. Adopting a perspective based on gender and class, this paper examines the work of the female Chinese artists of the late 19th century both in the traditional Jiangnan area, which had been the epicentre of culture and economy, and in the newly developing trade areas, most notably Shanghai. There a vibrant art market emerged, bringing significant opportunities for women artists from broader social strata. This dynamic is illustrated by the particular example of Ren Xia. In these circumstances significant changes took place in the context of the presence of continuity in women's aesthetic production, while a traditional male discourse remained hegemonic.
\end{abstract}

Keywords: Late Imperial China; 19th century; women artists; Ren Xia; Jiangnan.

\section{INTRODUCTION}

The application of contemporary gender perspectives to the historical examination of Chinese women's art has served to enhance comprehension of its presence during the late Qing Dynasty (1644-1911). The work of American scholars Marsha Weidner and Ellen Johnston Laing in the 1980s, alongside other collaborators, provided artistic guidance to what was to be the first ever exhibition of Chinese women's paintings; 'Views from Jade Terrace: Chinese women artists, 1300-1912'; held at the Indianapolis Museum of Art in 1988. Complimentary to the 
exhibition was the publication of a collection of related articles and paintings announcing the beginning of a new approach to research on Chinese women's art.

As feminist ideas were transmitted to China, in the mid-1990s, local scholars began to develop theoretical frameworks and methodologies to examine the study of women's art in China. In 1995, the Beijing Palace Museum's 'Ming [1368-1644] and Qing Women's Painting Exhibition', based on the Museum's own collection, brought to the fore works from late imperial China, which served to reveal the flourishing and prosperous nature of the visual art that had been produced by women artists. Another exhibition held in the Zhejiang Museum of Hangzhou, during November and December 2017, exhibited women's painting from the Ming and Qing dynasties. Under the Chinese name of 流芳未歇：一明 确时期女性画家作品 ('Groundbreaking Female Artists of the Ming and Qing Dynasties') the exhibition marked a turning point, opening up further potential for the study of Chinese women's art (see Fig.1).

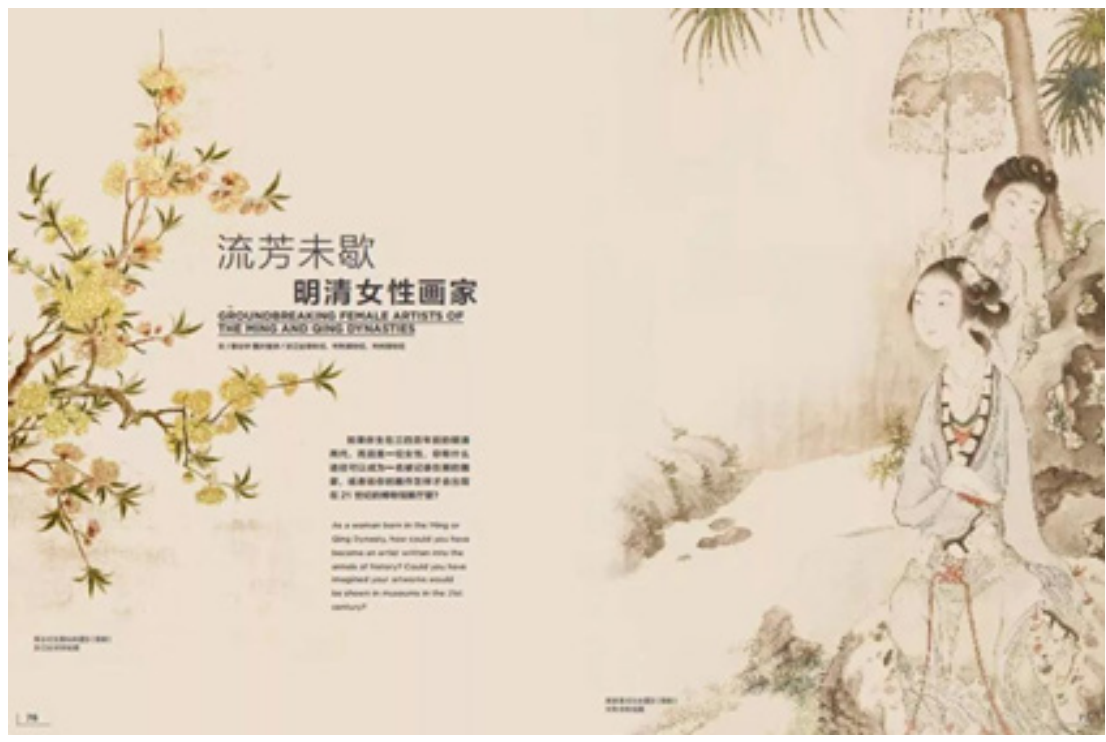

Fig. 1 Poster for the exhibition 'Groundbreaking FemaleArtists of the Ming and Qing Dynasties' http://kuaibao.qq.com/s/20180308B0QBGG00?refer=spider

\section{Statement of the problem}

The problem addressed is one whereby the chronicling of Chinese women's art effectively ceased, to all intents and purposes, in the earlier part of the 19th century. This was mainly as a result of the death of Tang Shuyu (汤漱玉, 18011830), a gentry woman born into a cultured family. Tang compiled Yutai Huashi 
(玉台画史The History of Jade Terrace Painting), published posthumously with the assistance of her husband. The work consists of written historical introductions to notable women artists and their works and is an important source for identifying the existence of a real 'herstory' of Chinese art. Among the 237 female painters compiled by Tang, 104 were working during the Ming Dynasty and 72 in the early and middle Qing Dynasty. Although later scholars compiled introductions to celebrated women of notable talent (Li, G., 1995; Lee et al., 2015), records of women artists more generally of 19th century are scattered and not catalogued or stored appropriately. While Li Shi; a curator and researcher at The Palace Museum, Beijing; played an important role in the legitimating of women's position in art history by her consistent study on women artists in the Qing Dynasty, it is striking that her attention to the late Qing in the 19th century is insufficient. In such circumstances, the treasure trove of Chinese women's art in the 19th century is somewhat more difficult to study due to circumstances whereby it is largely hidden from our historical vision.

In such circumstances, it should come as no surprise that many creatively and actively engaged Chinese women artists have been hidden from history. It has been the perception that the proliferation of women's artistic production, prevalent during the 17th and 18th centuries, gave way to a decline in women's art in the 19th century. In my research I have subjected this concept to interrogation I believe that it is untrue and that for various reasons the artistic work of Chinese women in the 19th century, especially its later part, has been ignored or undervalued.

In identifying the historical reality of the proliferation in the amount of working women artists in China during the 19th century I address the questions: how did the process of historical exclusion of 19th century women come to be, with the women's art of that period having largely being ignored? By focussing on the paintings, themselves, can we identify the extent to which there was continuity in the nature and quality of women's art throughout the Qing Dynasty? Or might we identify significant change and/or decline as the 19th century progressed?

In presenting these three key questions, I do so base on my own hypothesis that, contrary to conventional wisdom, we see continuity in the quality of the women's art of the $19^{\text {th }}$ century rather than a break and, indeed, we see certain aspects of progress and development. The scope of this work is limited. As such I have drawn upon the exhibition 'Groundbreaking Female Artists of the Ming and Qing Dynasties' alongside the presentation of a case study of Ren Xia, an individual female artist who, in many ways, exemplifies that symbiosis of continuity and change as China entered modernity. 


\section{LITERATURE REVIEW}

The aforementioned exhibition 'Views from Jade Terrace' of 1988 had paved the way for Chinese scholars to research the women's art of the late imperial period by providing inspiration to the key scholar Li Shi (1995; 1998; 2008;), and other scholars (Tao \& Li, S., 2000; Li, Y., 2008; Liao, 2005; He, 2008; Xiao, 2007; Cao, 2013; Zhao, 2018). In drawing upon the literature, I make the case for a historical continuity in the presence of artistic work by Chinese women stretching back to the later Ming Dynasty and into the Qing Dynasty. However, in doing so, existing published work also records that the late Qing Dynasty was a period that stands out as one in which women's painting was able to flourish both within the traditionally artistic cities in the South of the Yangtze River and then in the emerging port cities, most notably Shanghai.

Broadly speaking, the literature to which I have referred indicates that during $17^{\text {th }}$ century an emergence of urban prosperity, mainly centred in the Jiangnan area of southern China had seen the advance of a broader art market (Ko, 1992, 1994; Cao, 2013; He, 2008; Li, S., 2008). It should be recognised that Jiangnan was less a physical area with unequivocal boundaries than an economic way of life and a cultural identity. In geographical terms, the heart of Jiangnan during the $17^{\text {th }}$ and $18^{\text {th }}$ centuries coincided with the drainage area of Lake Tai in provinces of Zhejiang and Jiangsu (Ko, 1994; Mann, 1997). This shift toward urbanization and the consequent rise of a print culture saw an increase in the number of books for women, more published work by women, and more discussion about companionate marriage and about intellectual engagement among women and between men and women from the $17^{\text {th }}$ century onwards (Mann, 1997).

These factors served to stimulate artistic development in circumstances that saw an emergent fledgling type of 'middle class' that would seek to emulate the upper classes, who venerated the role of culture and the arts created by an educated intelligentsia or 'literati' (Cao, 2013). A situation arose in which sections of the literati were beginning to accept into their rank's women of the talent with the creative capacity to produce artistic works (He, 2008). Such a position of encouraging female education and personal cultural progress dovetailed into a mentality amongst the upwardly socially mobile scholars to promote such attributes in order that the social position and status of their daughters, and consequently her family, might be enhanced by marrying into a family enjoying higher social status and privilege (Laing, 1990). 
It was especially in the Jiangnan region that women might reach higher status as an artist (Mann, 1997). By the opening of the $19^{\text {th }}$ century women artists had come to be drawn almost exclusively from a gentry family background, with courtesan female artists shunned in the High Qing (1683-1839) period (Laing, 1990; Mann, 2005; Cao, 2013; Li, S., 2008). Thus we see that in the $19^{\text {th }}$ century women artists were largely made up from the daughters, wives and mothers of the cultured families mostly based in the Jiangnan area (Li, S., 2008 ). Weidner (1988) and Li Shi (2008) both elaborate on how, in these circumstances, although the recorded history of Chinese artists during this period is essentially a history of male artists, the history of the Chinese female artists can easily be arrived at from these historical records due to the fact that outstanding women artists would be either connected by blood or by marriage to the male artists concerned or were linked to the schools and traditions of the masters. In general, women had the opportunity to paint the same subjects as the male artists (Weidner, 1988; Li, S., 2004). In the three categories of subject matter in China, the gentry women mostly painted flowers and birds, followed by landscape, and then figures (Laing, 1990). Their work on landscape and figures was subject to certain limitations, in terms of mobility based on norms of respectability (linked to age and marital status) and the physical difficulties presented by their bound feet and, to a lesser extent, by the presence of erotica in the genre of figure painting. Nevertheless, such limitations did not render these general subject areas prohibitive (Weidner, 1988). Women's painting, especially of the domestically located birds and flowers, would often be for self-enjoyment (Li, S., 2008) but would also be based on a similar motivation men's portrayal of such subject matter, that being to meet consumer demand (Weidner, 1988).

The judgements, in terms of the quality of these women's art are, however, somewhat diverse. Some authors (e.g., Liao, 2005; Li, S., 2008) place emphasis upon the oppression of women in Imperial China in the form of patriarchal morality. In doing so their analysis tends to be that women succumbed to the dominance of male artists and thus failed to create their own styles and their achievements failed anywhere to surpass those of their male counterparts. However, others have emphasised the inspiration that is evident in the content of the women artists' work. Despite the similarity in form and subject matter, which seems to be overwhelmingly influenced by dominant position of their male counterparts, they identify the presence of the women's intuition drawn from their depth of feeling about nature and their sense of social existence (Cao, 2013; Xiao, 2017). 


\section{Theoretical framework}

Starting from a traditional historical perspective, drawing upon secondary materials and on empirical examination of the artworks themselves, theoretical concepts serve as tools to analyse factors related to gender and socio-economic circumstances. I engage with Marxist methodology primarily to look at the influence of social class (but in a critical and non-rigidly structural way) and feminist methods of analysis to examine gender and the extent to which the sex of the female artists transcends, and interplays with, the influence of class and forms a key determining factor upon their work. In addition, I draw upon a broader cultural perspective to comprehend the influence of ideas as a material factor.

Engagement with such theoretical outlooks provides an opportunity to examine the social and cultural environments experienced by these women, which served to influence them aesthetically and ideologically. Such approaches present the potential to assess the extent to which the paintings produced by these women began to challenge the limitations placed upon them according to class and gender; with a broad cultural perspective serving to offset the danger of a rigidly structural approach, thus allowing some assessment of the extent to which the aesthetic and ideological influences from within their cultural milieu and wider cultural influences served to offset the influences of class and gender relations.

\section{Retrospective on women artists of the later 19th century from the exhibition}

Jiangnan continued to form the main component of women's artistic production

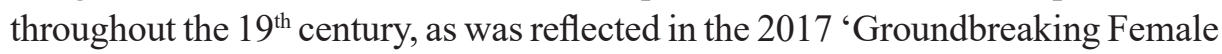
Artists' exhibition which served as a great stimulus to ever deeper insight into 'herstory' of art. The exhibition presented the works of more than thirty women artists, including paintings from women artists working in the later part of the 19th century. I have identified twelve such artists whose work was exhibited, namely: Wang Caiping (王采苹), Gu Shao (顾韶), Li Jue (李珏), Ren Xia (任 霞), Xu Baozhuan (徐宝管), Zuo Xixuan (左锡璇), Miu Jiahui (繆嘉惠), Hua Yaomei (华瑶妹), Zhou Jiarui (周家芯), Qian Juying (钱聚瀛), Zhuang Yaofu (庄曜孚), and Shen E (沈萝). The works of the exhibited artists concerned were drawn from holdings in the Zhejiang Provincial Museum itself, and from the Changzhou Museum and the Changshu Museum (both in Jiangsu province).

In the $19^{\text {th }}$ century, female painters were mostly influenced by the work of Ming and Qing male literati painters. Their subject matter was largely based 
on natural landscapes such as: rocks, water, with the people being placed in the context of the landscape; as well as flowers and birds, those being the subject matter traditionally associated with female artists.

Such representation should be understood not as the presentation of pure natural objects, but rather as the incarnation of lofty sentiments. This is exemplified in three freehand flower paintings shown in the 2017 exhibition: Li Jue's Lotus Painting (1893, silk, Changzhou Museum); Gu Shao's Colourful Flower (See Fig.2); and Zhuang Yaofu's Peony Painting, (1889, Changzhou Museum). These paintings are composed through the use of ink and color in an attempt to accurately express the flower's flamboyant and prosperous form. There are also some figure paintings with characters as their subject matter, such as Wang Chen's painted screens entitled Ladies (Changshu Museum) and Zhou Jiarui and her Two Ladies painting (See Fig.3). The characters are not isolated in the paintings, but are integrated into the environment. Both the characters and scenery emphasize what has been described as 'the combination of both form and spirit', thus seeking a high degree of unity between the art form and subject consciousness, the subject's essence. In Miu Jiahui's Landscape and Lady painting (See Fig.4), lakes, mountains and rivers are the main objects of description, and the characters add a sense of vitality. Houses, trees, flower, lakes and characters form a harmonious and vivid picture.

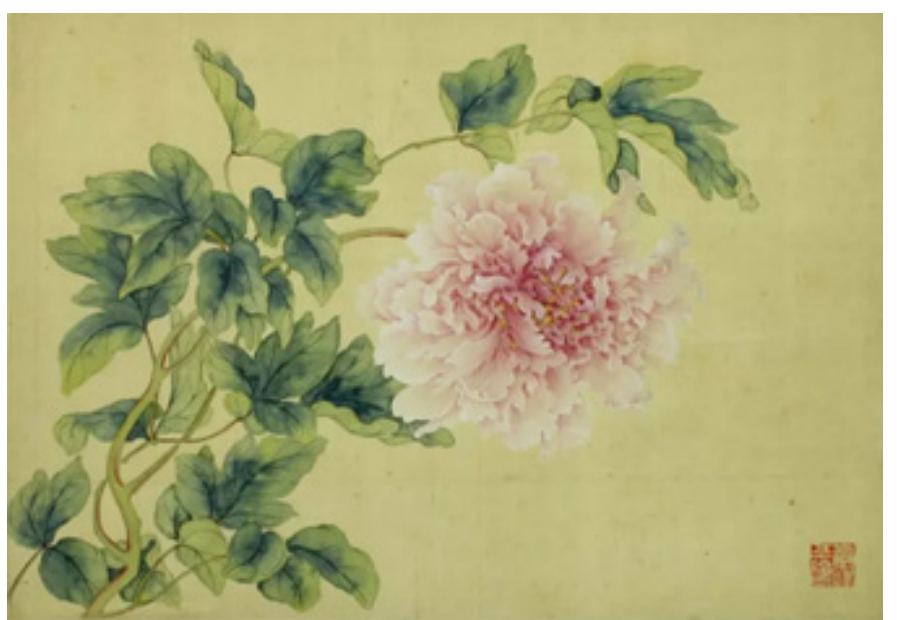

Fig. 2 Colourful Flower, Gu Shao, color on Xuan paper, 1858, Zhejiang Provincial Museum. 


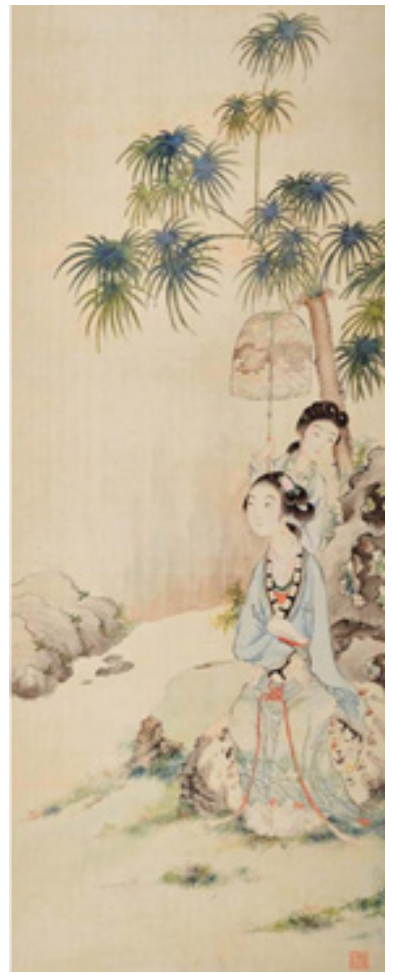

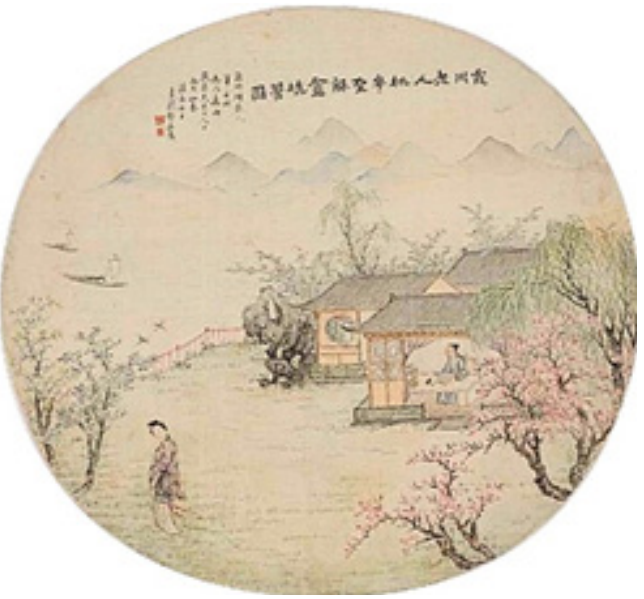

Fig. 4 Landscape and Lady, Miu Jiahui (1841-1918), 1886, Zhejiang Provincial Museum.

Fig. 3 Two Ladies, Zhou Jiarui (n.d.-1917), Colour on silk, Changshu Museum.

These works clearly reflect expression of the emotions that were expected of the female painters based around delicacy, which was perceived as being unique to women. Such gentleness and exquisiteness are communicated by the elegant use of colour and ink. Through their continuous absorption and application of the traditional concepts of Chinese humanities and artistic achievements, female painters sought to unify what were perceived as women's unique psychological and emotional expressions, thus shaping the perception of a woman's unique personality charm.

While it is clear that the exhibition reflects the continued dominant position of the traditional Jiangnan area as the epicentre of women's art, it is nevertheless the case that the increasing importance of Shanghai can be discerned by the fact that two of twelve women artists featured in the exhibition, who can be identified as having been active in the later $19^{\text {th }}$ century, had worked in Shanghai as professional artists. These being Zhuang Yaofu, who would base herself in Shanghai for a period, and Ren Xia who, as a consequence of her father's career 
move to Shanghai, was born there and worked all her life there as a professional artist. Also, other prominent female artists as Wu Shujuan, Yang Wensen, Song Zhen, had followed their fathers, husbands, or other family members to Shanghai (Sun, 2000). In so doing they were working in circumstances whereby women artists were increasingly able to manage their own careers, venturing outside the confines of the domestic sphere in order to earn money to maintain their family's finances.

In summary, during the $19^{\text {th }}$ century the primary geographical area of operation for Chinese women artists remained the traditional cultural area of Jiangnan. However, as the century unfolded, the growth of Shanghai's, and of other trading port cities', vibrant and dynamic art markets brought with it the potential for women artists of limited economic means to make a living from their work, thus broadening the sociological composition of women artists able to dedicate their time and energy to perfecting their skills. In these circumstances, women artists were emerging as truly career painters.

\section{Ren Xia, a women artist fusing the popular and the traditional in new market conditions}

Ren Xia (1870-1920), was born in Shanghai as a consequence of her father Ren Bonian's migration into that city in 1868. Ren Bonian (1840-1895), the son a rice merchant, was to become a giant of the Shanghai School of painting, which fused popular and traditional styles in order to cater for demand. The Ren family originated from Shaoxing in the Jiangnan region (Wang, 2003).

The life and work of Ren Xia was chronicled by the late Qing Dynasty scholar Zhang Mingke (1987:160). He recorded that Ren Bonian specialised in the production of figure landscapes and that Ren Xia systematically began the process of copying her father's legacy works and his techniques and forms of expression. Zhang goes on to record how Ren Xia, in the aftermath of her father's death, was asked by collectors to copy her father's works, presenting them as if they were the work of Ren Bonian himself. In such circumstances Ren Xia's copies became largely indistinguishable from her father's original paintings. It is thought by some scholars that most of such copies were perhaps inscribed with what appeared to be the signature of Ren Bonian himself (Bao \& Jia, 2012; Tao \& Li, S., 2000; Zheng, 1947).

There are three key points to be drawn out. Firstly, that Ren Xia had been reliant almost totally on her father's artistic tutorship. Secondly, Ren Xia, for 
want of a better term, might be described as a 'ghost painter' in regard to some of her work. Finally, I wish to present the case that her works were indeed of a high quality.

Even though Ren Xia was born into a literati family of high renown within the art circles, it would be an error to see her as an elite daughter. Unlike the daughters of the upper gentry families, she was unable to gain a developed broad education, inclusive of culturally enhanced recreational pursuits based upon Confucian morality. Ren Xia's enterprising merchant family required of her a more utilitarian function, as their economic stability was only as good as their continued capacity to sell paintings.

In the aftermath of Li Shi's inspection of Ren Xia's paintings in 1995, Li came to the view that Ren Xia's artistic activities were concentrated before 1895, during Ren Bonian's lifetime. However, most of the works that were handed down were created after 1895 and were signed by Ren Xia herself, in her own name rather than bearing the name of her father. Li thought that most of Ren Xia's works were signed under her father's name before 1895, and that she did not sign her own name until after her father's death.

Ren Xia's lower social status has been linked to a perceived lack of creativity on her part by some modern contemporary scholars (Cao, 2013; Jiang, 2001; Li, S., 1995, 1998, 2008; Tao \& Li, 2000; Wang, 2003), being unable to create her own distinctive style. These authors have tended to assert that while Ren Xia's work showed her ability to imitate her father's brushwork and his compositional style, in the process of acquiring such skills she had buried her potential to develop innovative capacity.

Tao and $\mathrm{Li}$ (2000) pointed to great differences between father and daughter, in terms of their quality of artistic attainment, rather than identifying and giving emphasis to a difference in their forms of artistic expression and without considering that perhaps Ren Xia's best work was done in the name of her father. For Tao and Li, Ren Bonian was the superior and Ren Xia the inferior - a talented female painter with a rare ability as a ghost and copy painter. Accordingly, in their observations of the father and daughter artists' versions of Fengchen sanxia (Three chivalrous travellers), they draw from it that Ren Xia merely copied her father's work, which served to weaken the pioneering nature of her capacity for artistic innovation and creativity. Her creative development was impeded, due to lack of time, which related to her economic and social circumstances and also to her sex. According to Jiang (2001), the necessity for her to work as a ghost 
painter rendered her with too little time to conceive of and create her own work, a position that was compounded by her being bound by feudal thought, thus unable to realize her own skills as a painter.

However, Ren Xia was an able woman artist, with the ability to create high quality figures, landscapes, and flower and bird paintings. Her works, like her father's, were a fusion of the literati painting traditions combined with popular aesthetics. With such a broad repertoire to work upon she was very capable of meeting the demands and opportunities of the Shanghai art market, inclusive of an ability to adopt appropriate market strategies. Such was the extent of her abilities that $\mathrm{Xu}$ Beihong, the Principal of the Central Academy of Fine Art, asserted in 1950 that Ren Bonian's daughter, who had studied from her father, could "really do the masterpieces" (as cited in Gong, 1982: 2).

When assessing Ren Xia's contribution to the world of art, it is consequently important to recognize that she was a woman who did not enjoy the advantages shared by the traditional Guxiu (genteel women) who had received a good education from within an affluent family, and were therefore devoid of the pressure to produce for sale, leaving time for contemplation and the exploration of their thoughts and feelings, as well as the development of wider techniques.

Jiang (2001), interestingly, goes on to make the observation that Ren Xia's paintings differ from those of such genteel women whose pictures were more in conformity with the Confucian mentality of the natural attributes of woman: peaceful in mentality as they express their joy in the delicate depiction of flowers and birds, as compared to Ren Xia's bolder in use of brush and colour, as we see in her depiction of 'Zhong Kui', (an immortal, Fig.5). Equally of significance is that Ren Xia was rich and sophisticated in her application of technique, having had the chance to accept formal training from her father. 


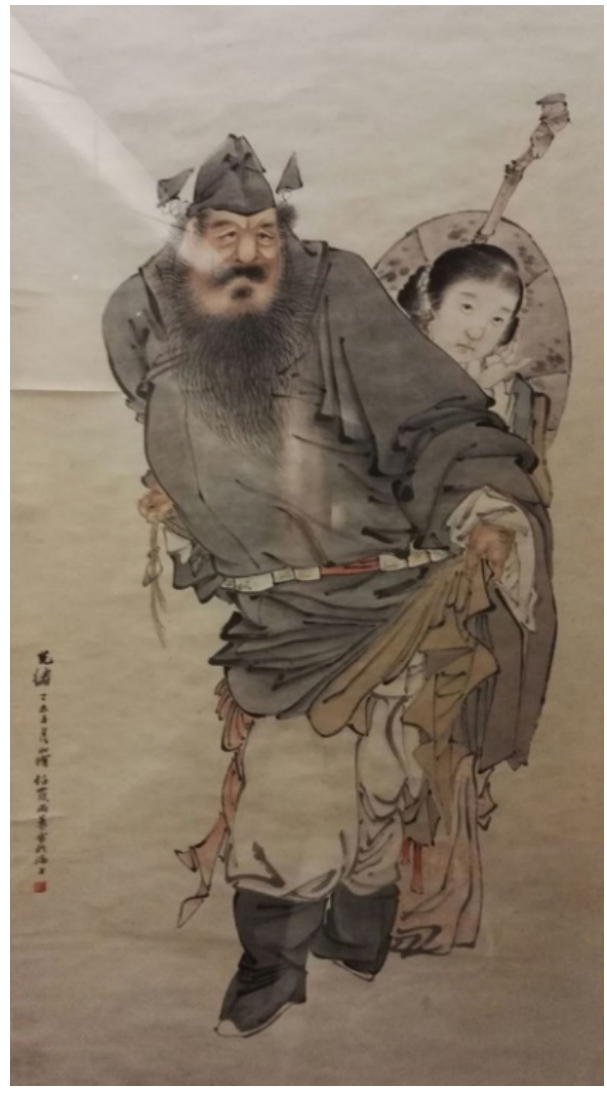

Fig. 5 Zhong Kui, Ren Xia, 1907; colour on paper, in the 2017 exhibition, Zhejiang Provincial Museum.

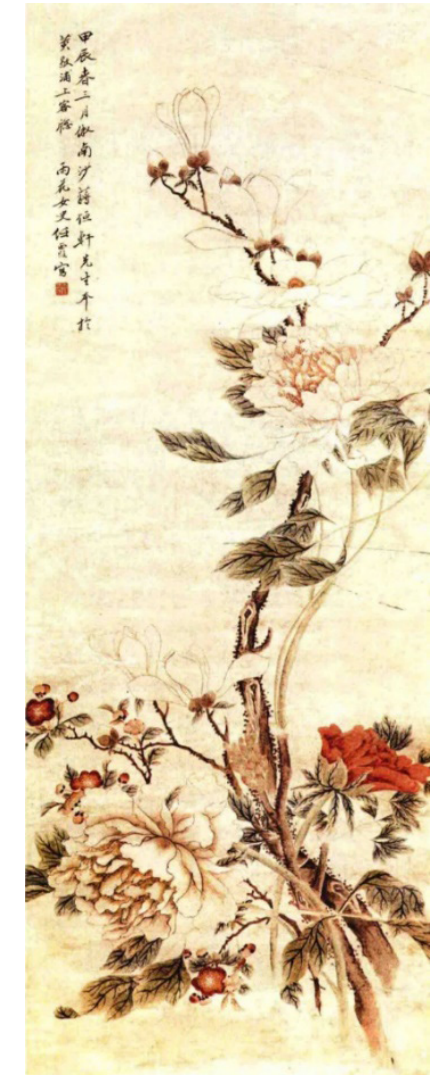

Fig. 6 Peonies and Magnolia, Ren Xia, 1904, color on paper, in the 2017 exhibition, Zhejiang

Provincial Museum.

In terms of my own assessment of Ren Xia, I am drawn to question the extent to which the difference in the forms of artistic expression of Ren Xia and Ren Bonian are primarily differences in ability rather than differences of aesthetic sense. In considering this matter one is drawn to examine the extent to which various differences in their aesthetic perception arise as a consequence of their differing social and personal experience, perhaps not least of those being the differences in experiences based on sex and patriarchy.

The real question is the extent to which Ren Xia was able to develop as an artist in her own right, standing on the shoulders of Ren Bonian, rather than at his feet as a mere copy painter. Tao and Li, and Zhao (2013) acknowledged Ren Xia as a great artist in her own right. Zhao (2013: 1223) refers to Ren Xia's 
1904 Peonies and Magnolia (Fig. 6) which she created after the work of Jiang Tingxi (1669-1732), remarking that her technique and drawing was highly skilled to the point of "creating an exquisite work of art with its own distinctive features". He described how Ren Xia observed the characteristics of different kinds of flowers in the painting very carefully, especially the weight of the flowers, and the texture of the water vapour which are depicted in vivid fashion. Significantly Zhao explicitly identifies a key aspect in the aesthetic production of the work being its expression of "the unique emotional experience of women", emphasizing the difference in the way she uses the pen, as compared to the male painter upon whose work she bases the picture. As such, Zhao argues that the work should be categorized as a "re-creation" rather than merely as a "copy", despite the fact that Ren Xia herself, in the inscription on the work, defines it as a copy of Jiang Tingxi's painting. Zhao attributes the prevalence of the copying of historic works in Ren Xia's work to circumstances in which artists found great difficulty in gaining acceptance of their self-created works in the market conditions within which they were operating.

Of greater significance than Zhao's emphasis on the presence of extremely high technical skills in Ren Xia's work is that he explicitly credits her with the capacity for creating an exquisite work of art with its own distinctive features, which cannot be interpreted as merely constituting copying. Additionally, Bao Mingxin and Jia Yiliang (2012), also credited Ren Xia with conveying through her work the unique emotional experience of women, which, equally, cannot be seen as merely the product of the technical abilities taught to her by her father. As such one might more consider that her combination of such technical skills with exclusively feminine aesthetic capacities constituted a significant contribution to Chinese art.

As we see in the particular case of Ren Xia, controversy tends to be cantered on whether women artists of the late Qing possessed outstanding aesthetic qualities, as opposed to simply imitating the techniques of the masters. It remains the opinion of many scholars that the paintings of women in the Qing Dynasty cannot be seen to have broken from under the shadow of the male counterparts, often continuing to be limited in terms of subject matter and to the adoption of existing forms of aesthetic expression that were essentially derived from a male perspective and based on the utilization of artistic techniques that remained consistent with those of male artists. Underlying such assumptions is the concept that the subordinate position of women continued as a consequence of the long-term profound influence of feudal thought on Chinese women, thus serving to shape their willingness to accept a relationship of obedience to men. 
Nevertheless, even if one accepts such an evaluation of women's painting from the later Qing period, one is still drawn toward recognition of the presence of some distinction between the works of men and women, based on the latter's depiction of individual feelings, emotions and forms of expression, in contrast to the formality of expression based upon social and political concerns that was associated with the work of male painters.

\section{CONCLUSION}

As the Imperial period began to draw to a close, I contest that we can identity a long continuity in the presence of women's artistic creativity, including among those of a somewhat lower socio-economic position. Nevertheless, most of the female painters were from cultural families, with their way of learning and painting still based on education through the family, with more often than not the initial purpose of those who came to the new markets, most notably Shanghai, being to stay together with their husbands or fathers and thus seek to ensure survival. Nevertheless, many of them would continue to explore art as they navigated the road to survival, and in doing so they would gradually expand their influence and career choices. These female painters of the later $19^{\text {th }}$ century differ from those going before, in that they had more social opportunities in the public sphere as professional artists. Such opportunities were compounded by socio-economic changes that brought with them new prospects in education and recreation for girls and women.

Up until the second quarter of the $19^{\text {th }}$ century, historical understanding of Chinese women artists is primarily a project of comprehending the culture of gentry women and of concubines who had operated in a wholly subordinate position to gentry men. As the dominant position of the gentry began to fade, nevertheless the norms and values of Confucian culture continued to resonate. The role of daughter, future wife and mother continued to maintain a predominant place in the cultural expressions of women artists, reflecting the presence of continuity in female behaviour and values. One might understand the continued weight and depth of such mentalities in the context of cultural inertia; with the culture of the declining gentry persisting in playing its part in the dissemination of morality and values that were reliant on the presence in the family of women who could hand down to the next generation of females the talents of artistic creativity and the associated psychological traits associated with high morality. Nevertheless, the prevalence of such mentalities, somewhat contradictorily, in the new circumstances paved the way for wives to cooperate with their husbands in producing poetry and paintings, travelling and socially communicating, which 
constituted the best lifestyle to be pursued by women in order that they might fulfil the role that was expected of them. However, the development of new social thought, based on the needs presented by socio-economic changes during the mid to late $19^{\text {th }}$ century, opened up space for an expansion of the work of female painters, especially in Shanghai after the first Opium War. These developments marked not only a cultural shift but also a geographical one as the focus of women's artistic production began to shift away from the traditional cities of the Jiangnan area and toward the new port city metropolises.

In conclusion, by way of repetition, we must recognise that women's artistic creativity was ever-present throughout the period covering late Ming Dynasty and the Qing Dynasty. However, in spite of huge changes during the latter part of the Qing Dynasty, in terms of the opportunities that opened for the fuller participation of women in the art market, such for revolutionary change was tempered by the deep resonance of traditional Confucian culture, which served to ensure that women's artistic expression continued to be dominated by the norms of male discourse and entwined with foundations of the family.

\section{REFERENCES}

Bao, M. \& Jia, Y. (2012). Four Ren family heirs (四任传人). Shanghai: Donghua University Press.

Cao, Q. (2013). Research on the paintings and calligraphies of Ming and Qing Dynasties genteel women (香闺缀珍: 明清才媛书画研究). Nanjing: Jiangsu Meishu Chubanshe.

Gong, C. (1982). Research on Ren Bonian (任伯年研究). Tianjin: Tianjin Renmin Meishu Chubanshe.

He, J. (2008). Special talents in painting: women's paintings at the end of the Ming to the beginning of Qing (丹青奇菂: 明末清初的女性绘画). Beijing: Wenwu Chubanshe.

Jiang, Y. (2001). Ren Xia and her art (任霞和她的艺术). Journal of Nanjing Arts Institute Fine Arts and Design. 3: 25-27.

Ko, D. (1992). Pursuing talent and virtue: education and women's culture in Seventeenthand Eighteenth-Century China. Late Imperial China, 13(1): 9-39. 10.1353/ late. 1992.0002

Ko, D. (1994). Teachers of the inner chambers: women and culture in SeventeenthCentury China. Stanford: Stanford University Press. https://www.sup.org/books/ title/?id=2824

Laing, E. J. (1990). Women Painters in Traditional China. In Weidner, M. (ed.) Flowering in the Shadows: Women in the History of Chinese and Japanese Painting, pp. 81-102. University of Hawaii Press.

Lee, L. X. H., Lau, C., \& Stefanowska, A. D. (eds.). (2015). Biographical dictionary of Chinese women: v. 1: the Qing period, 1644-1911. M.E. Sharpe. Reprint, London and New York: Routledge. 
Li, G. (ed.). (1995). A brief biography of women painters from ancient to present (中国 古今女美术家传略). Beijing: Zhonggong Zhongyang Dangxiao Chubanshe.

Li, S. (1995). Ren Xia's ghost paintings in Ren Yi's figure painting (任臨人物画中的任 霞代笔做). Collectors, 3: 48-50.

Li, S. (1998). Li Shi talks about the ancient Chinese women's paintings (李湜谈中国古 代女性绘画). Changchun: Jilin Social Science Publishing House.

Li, S. (2004). The paintings of the courtesans and gentry women in the Ming-qing Dynasties (明清时期的闺阁妓女绘画). Chinese Painting \& Calligraphy, 7:56-62.

Li, S. (2008). A study of paintings from the inner quarters during the Ming and Qing periods (明清閨閣绘画研究). Beijing: Zijincheng Chubanshe.

Li Y. (2008). Research on “The History of Jade Terrace Painting” (《玉台画史》研 究). Doctoral dissertation, Nanjing Normal University.

Liao, W. (2005). Green fat red thin: female image and guige arts of the ancient arts (绿 肥红瘦：古代艺术中的女性形象和闺阁艺术). Chongqing: Chongping Publishing House.

Mann, S. (1997). Precious records: women in China's long Eighteenth Century. Stanford: Stanford University Press. https://www.sup.org/books/title/?id=2894

Mann, S. (2005). The virtue of travel for women in the late empire. In Gender in Motion: Divisions of Labor and Cultural Change in Late Imperial and Modern China, edited by Goodman, B. \& Larson, W., pp.55-74. Rowman and Littlefield Publishers.

Sun, J. (2000). Ancient Shanghai Art (古代上海艺术). Shanghai Daxue Chubanshe.

Tang, S. (1963) The History of Jade Terrace Painting (玉台画史). Shanghai: Shanghai Renmin Chubanshe. (Original work published 1831).

Tao, Y. \& Li, S. (2000). A lost history: the history of Chinese women's painting (失落的 历史：中国女性絵画史). Changsha: Hunan Meishu Chubanshe.

Weidner, M.; Laing, E. J.; Lo, I. Y.; Chu, I. \& Robinson, J. (1988). Views from jade terrace: Chinese women artists, 1300-1912. Indianapolis Museum of Arts and Rizzoli International Publications.

Wang, X. (2003). Giant of the Shanghai School: Ren Bonian (海派巨擎: 任伯年). Fuzhou: Haixia Wenyi Chubanshe.

Zhang, M. (1987). A record of discussions of art from the Hansong Pavilion (寒松阁谈 艺琐录). Shanghai: Shanghai People's Fine Arts Publishing House.

Zheng, Y. (1947). Xiao Yang Qiu (小阳秋). Shanghai: Rixin Chubanshe.

Zhao, Q. (ed.). (2013). An Appreciation of Chinese paintings through the Dynasties (中 国历代绘画鉴赏). Beijing: Shangwu Yinshuguan Guoji Youxiangongsi. 